\begin{tabular}{|c|c|c|}
\hline \multirow{2}{*}{ Ma } & $\begin{array}{l}\text { Науковий вісник НЛТУ України } \\
\text { Scientific Bulletin of UNFU }\end{array}$ & \begin{tabular}{|l|l} 
(c) 1 ISSN 1994-7836 (print) \\
BY ISSN 2519-2477 (online)
\end{tabular} \\
\hline & https://nv.nltu.edu.ua & \\
\hline НАТТА & https://doi.org/10.36930/40310219 & $@ \bowtie$ Correspondence author \\
\hline & $\begin{array}{l}\text { Article received 29.03.2021 p. } \\
\text { Article accepted 29.04.2021 p. }\end{array}$ & $\begin{array}{r}\text { D.V. Fedasyuk } \\
\text { dmytro.v.fedasyuk@lpnu.ua }\end{array}$ \\
\hline & UDC 004.738.5:316.[728+772] & \\
\hline
\end{tabular}

Т. П. Білецький, Д. В. Федасюк

Національний університет "Львівська політехніка", м. Львів, Україна

\title{
ПРОГНОЗУВАННЯ ДЕФЕКТІВ У ПРОГРАМНОМУ ЗАБЕЗПЕЧЕННІ АЛГОРИТМАМИ ГЛИБИННОГО НАВЧАННЯ CNN TA RNN
}

\begin{abstract}
Досліджено процес прогнозування дефектів у програмному забезпеченні (ПЗ) з використанням алгоритмів глибинного навчання. Показано, що цей процес складається з декількох основних етапів: пошук та підготовка даних, побудова абстрактного синтаксичного дерева (АСД), обхід дерева та кодування значень вершин у цілі числа, збалансування даних, побудова та навчання нейронної мережі. З'ясовано, що застосування цього процесу прогнозування дефектів у ПЗ може пришвидшити та полегшити пошук дефектів та відповідно знизити вартість їх виправлення. Встановлено, що передові алгоритми машинного навчання, які на цей момент використовуються на етапі побудови та навчання нейронної мережі, досі $\epsilon$ недостатньо ефективними, щоб можна було застосовувати прогнозування дефектів у комерції, демонструючи нестабільну точність 40 60 \%. За результатами досліджень встановлено, що застосування алгоритмів глибинного навчання дає точніші результати, ніж інші алгоритми машинного навчання. Для зниження дисперсії та підвищення середньої точності прогнозування запропоновано новий метод прогнозування дефектів у ПЗ на підставі поєднання двох останніх модифікацій алгоритмів глибинного навчання CNN та RNN за допомогою бінарного класифікатора логістична регресія. Проведено навчання нейронної мережі на наборі даних розміром 50000 файлів вихідного коду, отриманих з 13-ти проєктів мовою Јava. За результатами досліджень виявлено, що метод CNN+RNN в середньому дає на 10-9\% вищу точність, ніж RNN та на $2 \%$ вищу точність, ніж $\mathrm{CNN}$, що доводить доцільність використання поєднання алгоритмів глибинного навчання у задачі прогнозування дефектів. Проаналізовано точність методу CNN+RNN по кожному з ПЗ проектів з набору даних, унаслідок чого виявлено, що для 11ти з 13-ти проєктів поєднання CNN+RNN дає не меншу точність, ніж окремо взяті CNN та RNN.
\end{abstract}

Ключові слова: надійність ПЗ; згорткова нейронна мережа; рекурентна нейронна мережа; машинне навчання.

\section{Вступ}

Дефекти програмного забезпечення (ПЗ) - це помилки у програмному коді, які призводять до неправильної чи неочікуваної роботи програмної системи. Прогнозування дефектів у ПЗ - це один із процесів етапу тестування ПЗ, який полягає у пошуку фрагментів коду, які потенційно містять такі дефекти. Тільки у 2017 р. через дефекти у ПЗ було зафіксовано 606 збоїв, які торкнулися половини населення світу (3,7 млрд людей), 314 компаній та завдали збитків на понад 1,7 трлн доларів [14].

На сьогодні, вартість пошуку та виправлення дефектів є одними із найдорожчих процесів у розробленні П3. На етапі імплементації пошук та виправлення дефекту коштує \$977, на етапі тестування вартість зростає до $\$ 7,136$, а етапі технічного обслуговування - до 14102 доларів [13].

Автоматизація прогнозування дефектів дає змогу підвищити якість ПЗ та знизити його кінцеву вартість [4]. Автоматизоване прогнозування дефектів під час тестування та підтримка спрощує для інженерів тестування завдання пошуку дефектів та знижує вартість виправлення помилки $[6,12]$. Позаяк автоматизовані методи пошуку дефектів, які на цей момент використовують на практиці, можуть бути покращені новими моделями прогнозування дефектів [7].

Прогнозування дефектів у ПЗ є затребуваним процесом у комерційних проєктах 3 розроблення складних програмних систем. Однак, на цей час, найкращі алгоритми машинного навчання, які використовуються для пошуку дефектів, все ще $\epsilon$ недостатньо ефективними, демонструючи нестабільну точність 40-60 \% [3, 10].

Об'єкт дослідження - прогнозування дефектів у ПЗ 3 використанням глибинних нейронних мереж.

Предмет дослідження - алгоритми глибинного навчання CNN i RNN та їх поєднання за допомогою бінарного класифікатора логістичної регресії для прогнозування дефектів у ПЗ.

Мета роботи - дослідження методів для прогнозування дефектів у ПЗ на підставі поєднання глибинного навчання CNN та RNN нейронних мереж, що забезпечить підвищення якості та функціональної придатності програмних систем.

Для досягнення зазначеної мети визначено такі оcновні завдання дослідження: реалізувати процес прогнозування дефектів у ПЗ з використанням запропонованого методу; натренувати нейронну мережу на реаль-

\section{Інформація про авторів:}

Білецький Тарас Петрович, магістрант, кафедра програмного забезпечення. Email: tbiletskyi@gmail.com

Федасюк Дмитро Васильович, д-р техн. наук, професор, завідувач кафедри програмного забезпечення. Email: dmytro.v.fedasyuk@lpnu.ua; https://orcid.org/0000-0003-3552-7454

Цитування за ДСту: Білецький Т. П., Федасюк Д. В. Прогнозування дефектів у програмному забезпеченні алгоритмами глибинного навчання CNN та RNN. Науковий вісник НлтУ України. 2021, т. 31, № 2. C. 114-120.

Citation APA: Biletskyi, T. P., \& Fedasyuk, D. V. (2021). Software defect prediction via ensemble of convolutional neural network and recurrent neural network. Scientific Bulletin of UNFU, 31(2), 114-120. https://doi.org/10.36930/40310219 
них даних та експериментальним шляхом визначити їі точність.

Наукова новизна отриманих результатів дослідження - розвинуто метод прогнозування дефектів у П3 на підставі поєднання алгоритмів CNN та RNN, який з вищою точністю прогнозує наявність дефектів у програмному коді.

Практична значущість результатів дослідження алгоритми глибинного навчання для пошуку дефектів у ПЗ можна використати для створення нових або розвитку наявних систем автоматизованого тестування програмних систем.

Аналіз останніх досліджень та публікацій. Для вирішення завдання прогнозування дефектів у ПЗ найпоширенішим є застосування алгоритмів машинного та глибинного навчання. У разі застосування традиційних алгоритмів машинного навчання прогнозування дефектів виконується на підставі аналізу якісних метрик коду: Halstead, McCabe, MOOD та інших [7, 15]. Найчастіше ці алгоритми $є$ бінарним класифікатором, який вчиться аналізувати неявні залежності між значеннями метрик у фрагменті коду та ймовірністю наявності дефекту у ньому. Поширеними бінарними класифікаторами для такої задачі $є$ Дерево рішень, Логістична регресія, Наївний баєсів класифікатор та Випадковий ліс (Random Forest) [11]. За результатами деяких індійських досліджень [12] виявлено, що у прогнозуванні дефектів найкраще показали себе алгоритми Random Forest та Наївний баєсів класифікатор. Натомість американські дослідники, виконавши експерименти застосувавши одразу усі найпоширеніші бінарні класифікатори - дійшли висновку, що однозначної відповіді який з них точніший - немає [11]. Ці результати підтвердили теорему "Безкоштовних сніданків не існує", яка стверджує, що два класифікатори є однаково ефективними, якщо розглядати їх на великому домені вхідних даних [19].

Останні декілька років дедалі поширенішими стають алгоритми глибинного навчання, які на відміну від традиційних алгоритмів машинного навчання, аналізують не якісні метрики коду, а безпосередньо сам код. Серед останніх опублікованих досліджень знайдено відомості про адаптовану Згорткову нейронну мережу $(\mathrm{CNN})$, яку в 2019 р. запропонували дослідники із Бейханського університету у Китаї. Вона показала на $30 \%$ точніші результати, аніж традиційні алгоритми машинного навчання та на $2.2 \%$ точніші відносно попередньої адаптації CNN [10]. Адаптація полягала у збільшенні кількості проміжних шарів мережі.

Цього ж року для прогнозування дефектів у ПЗ було запропоновано модифікацію Рекурентної нейронної мережі-Attention-Based RNN [3]. Дослідники із Шанхайського університету довели, що AR RNN на 7-14 \% $\epsilon$ точнішою за традиційні моделі машинного навчання та на 3-4 \% за попередні адаптації CNN та RNN. Модифікація RNN полягала у застосуванні Attention-методу для врахування нейронів на вихідному шарі із більшим ваговим коефіцієнтом.

За результатами аналізу виявлено, що прогнозування дефектів все ще $є$ недостатньо точними через дисперсність результатів відносно домену вхідних даних [8]. Тому для зниження дисперсії, у цій роботі запропоновано поєднати два найточніші алгоритми глибинного навчання - CNN та RNN [18].

\section{Результати дослідження та їх обговорення}

Особливості процесу прогнозування дефектів у П3. Запропонована у цьому дослідженні методика прогнозування дефектів у ПЗ складається із семи послідовних етапів (рис. 1). Розглянемо докладніше кожен із етапів цього процесу.

Пошук та підготовка даних. Для навчання нейронних мереж та проведення експериментів використано 50000 файлів вихідного коду 3 13-ти відкритих јavaпроєктів (табл. 1). Кількість дефектів та їх місцезнаходження у кожному з файлів отримано з відкритих джерел [17].

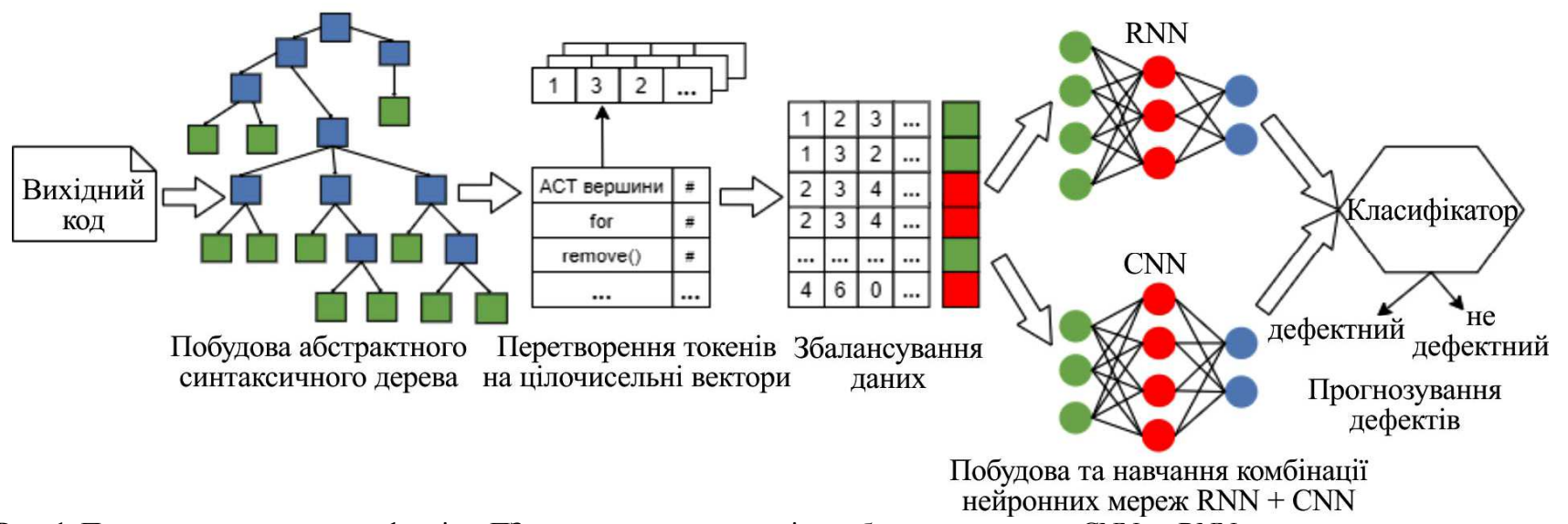

Рис. 1. Процес прогнозування дефектів у ПЗ поєднанням алгоритмів глибинного навчання CNN та RNN

Побудова абстрактного синтаксичного дерева. Для опрацювання нейронними мережами, вихідний код із датасетів має бути представлений у вигляді цілочисельних векторів. Існують різні рівні гранулярності подання програмного коду [20], однак найбільш зручним та ефективним є подання у вигляді абстрактного синтаксичного дерева (АСД), яке дає змогу зберегти, водночас, синтаксис та структуру програмного коду (рис. 2). АСД - це позначене і орієнтоване дерево, в якому внут- рішні вершини зіставлені з відповідними операторами коду, а листя - $з$ відповідними операндами. Дотримуючись загальноприйнятих підходів, розглядаємо тільки три типи АСД вершин [3, 6, 10]:

1) Вершини виклику методів та створення примірника класу.

2) Вершини оголошень змінних, параметрів, методів, класів, інтерфейсів і т.ін.

3) Вершини потоку керування: умови, цикли, порівняння і т.ін. 
Отже, у вершинах дерева зберігатимуться назви відповідних операторів чи операндів, які надалі назвемо токенами. Наприклад, для оператора циклу for ()$\{\ldots\}$ вершина дерева міститиме значення for, а для оголошення класу class $A()\{$.$\} вершина міститиме значен-$ ня $A$.

Табл. 1. Датасети для навчання та проведення експериментів

\begin{tabular}{|c|c|c|c|}
\hline Проєкт & Дата & Файли & Посилання \\
\hline Android Universal I. L. & $19-01-13$ & 480 & $\underline{\text { https://github.com/nostra13/Android-Universal-Image-Loader }}$ \\
\hline ANTLR v4 & $03-02-14$ & 2000 & $\underline{\text { https://github.com/antlr/antlr4 }}$ \\
\hline Broadleaf Commerce & $05-03-14$ & 12000 & $\underline{\text { https://github.com/BroadleafCommerce/BroadleafCommerce }}$ \\
\hline Eclipse p. for Ceylon & $08-10-14$ & 2000 & $\underline{\text { https://github.com/ceylon/ceylon-ide-eclipse }}$ \\
\hline Elasticsearch & $03-02-14$ & 4000 & $\underline{\text { https://github.com/elasticsearch/elasticsearch }}$ \\
\hline Hazelcast & $19-05-14$ & 4000 & $\underline{\text { https://github.com/hazelcast/hazelcast }}$ \\
\hline jUnit & $22-08-11$ & 2000 & $\underline{\text { https://github.com/junit-team/junit }}$ \\
\hline MapDB & $27-09-13$ & 900 & $\underline{\text { https://github.com/jankotek/MapDB }}$ \\
\hline mcMMO & $11-07-13$ & 1000 & $\underline{\text { https://github.com/nasa/mct }}$ \\
\hline Mission Control T. & $29-06-12$ & 1800 & $\underline{\text { https:/github.com/neo4 j/neo4 j }}$ \\
\hline Neo4 j & $09-04-14$ & 4200 & $\underline{\text { https://github.com/netty/netty }}$ \\
\hline Netty & $21-02-13$ & 3000 & $\underline{\text { https://github.com/orientechnologies/orientdb }}$ \\
\hline OrientDB & $10-12-13$ & 6000 & $\underline{\text { https://github.com/OryxProject/oryx }}$ \\
\hline Oryx & $10-11-13$ & 1300 & $\underline{\text { https://github.com/thinkaurelius/titan }}$ \\
\hline Titan & $09-10-14$ & 4200 & \\
\hline
\end{tabular}

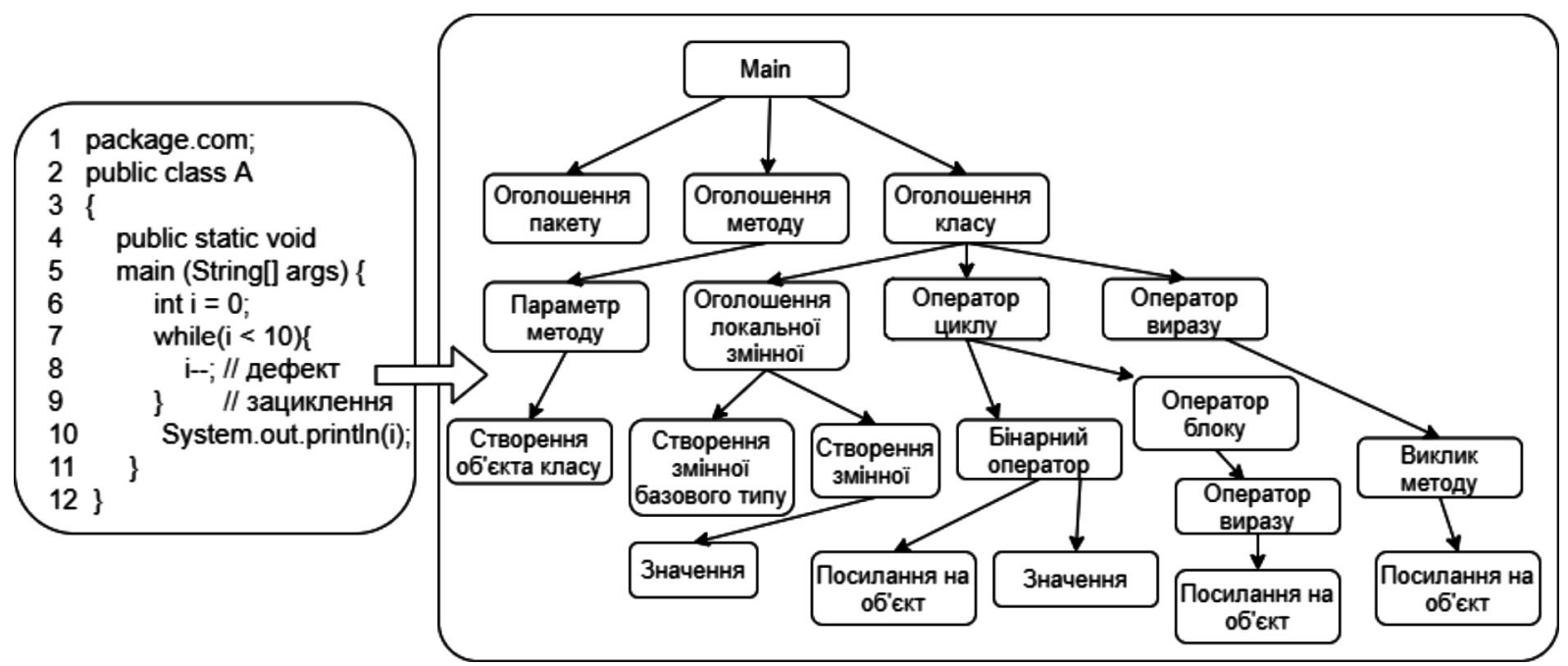

Pис. 2. Дефектний фрагмент програмного коду мовою програмування Јava та його представлення в АСД

Обхід АСД інфіксним алгоритмом та кодування у циілочисельний вектор. Наступним етапом є обхід АСД інфіксним (симетричним) алгоритмом та кодування отриманого вектора токенів у цілочисельний вектор. Для цього будується відображення між цілими числами та токенами. Кожен токен асоціюється з унікальним цілим числом, в межах від одиниці до загальної кількості унікальних токенів. Для кожного АСД формується вектор. Усі вектори вирівнюються по довжині, шляхом додавання нулів вкінець $[3,10]$. Окрім цього, під час кодування токенів відкидаються ті, що трапляються один або два рази - це поширена практика для підвищення точності нейронних мереж [6].

Збалансування даних. Датасети, які використовуватимуться у цьому дослідженні, є незбалансованими недефектних файлів значно більше, ніж дефектних. Ця проблема є поширеною: дослідження 106-ти публічних датасетів показує, що 87 \% 3 даних є середньо, або частково незбалансованими [16]. Навчання алгоритмів машинного навчання на таких даних може негативно вплинути на точність прогнозування дефектів [1]. Для вирішення цієї проблеми застосовано метод повторної вибірки, який полягає у дублюванні дефектних файлів [9].

Побудова нейронної мережі на підставі алгоритмів $C N N$ ma RNN. Запропонований метод базується на алгоритмах RNN та CNN, які об'єднані бінарним класифіка- тором Логістична регресія (рис. 3): навчання та проведення експериментів на кожній мережі виконується паралельно, а сумарні виходи аналізуються класифікатором, який вирішує чи файл містить дефект.

Перевагою нейронної мережі CNN $є$ потужна здатність генерувати властивості, які базуються на семантиці та локальній структурі вхідних даних - вихідного коду в нашому випадку. Натомість перевагою нейронної мережі RNN є здатність генерувати властивості, які базуються на довготермінових залежностях між даними (табл. 2).

Існує декілька підходів для поєднання алгоритмів глибинного навчання. У цій роботі обрали підхід Stacking - це коли навчання алгоритмів відбувається паралельно і вихід 3 кожного з них аналізується третім алгоритмом машинного навчання - класифікатором. У цьому випадку алгоритми CNN та RNN об'єднані за допомогою бінарного класифікатора логістична регресія [2]. Логістична регресія на вхід прийматиме ймовірності наявності дефекту, обчислені кожним 3 алгоритмів, та вирішуватиме, чи дефект присутній чи ні.

Для події $P$, яка може приймати два значення (1 дефектний, 0 - недефектний), модель логістичної регресії можна подати так [2]:

$$
P=\frac{e^{z}}{1+e^{z}}, \quad z=\theta_{0}+\sum_{j=1}^{n} \theta_{j} x_{j}, n=n_{1}+n_{2},
$$


де: $x_{1} \ldots x_{n}-$ значення, отримані на виході із CNN та чання нейронної мережі; $n_{1}$ та $n_{2}$ - кількість значень на $\mathrm{RNN} ; \theta_{0} \ldots \theta_{n}-$ коефіцієнти регресії, отримані в ході наввиході із CNN та RNN відповідно.

Табл. 2. Параметри нейронних мереж CNN та RNN

\begin{tabular}{|c|c|c|}
\hline & CNN & $\overline{\mathrm{RNN}}$ \\
\hline Embedding layer & 1 (output $\operatorname{dim}=32)$ & 1 (output $\operatorname{dim}=32)$ \\
\hline Convolutional layer & $3($ filters $=10$, kernel size $=2$, strides $=2)$ & - \\
\hline Bidirect LSTM layer & - & 3 (units $=40$ ) \\
\hline Pooling layer & $3($ kernel size $=2$, strides $=2)$ & - \\
\hline Flatten layer & 1 & 1 \\
\hline Dense layer & 3 (unites $=50$ ) & 3 (units $=24$ ) \\
\hline Activation function & $\begin{array}{l}\text { ReLU (усі шари, окрім останнього) } \\
\text { Sigmoid (останній Dense layer) }\end{array}$ & $\begin{array}{c}\text { Tanh (перший Dense layer) } \\
\text { ReLU (другий Dense layer) } \\
\text { Sigmoid (останній Dense layer) }\end{array}$ \\
\hline Parameter Init & $\begin{array}{l}\text { He_normal (усі шари окрім останнього) } \\
\text { Glorot normal (останній Dense layer) }\end{array}$ & Glorot_normal \\
\hline Dropouts & 2 (Між Dense layers), dropout rate $=0.5$ & - \\
\hline Regularization & $\mathrm{L} 2(12=0.0001)$ & - \\
\hline Loss function & Binary cross-entropy & Binary cross-entropy \\
\hline Optimizer function & Adam (learning rate $=0.0015$ ) & RMSprop (learning rate $=0.0015$ ) \\
\hline Batch size & 32 & 32 \\
\hline Epoch & 10 & 10 \\
\hline Early Stopping & monitor $=$ val loss, patience $=3$ & monitor $=$ val loss, patience $=3$ \\
\hline
\end{tabular}

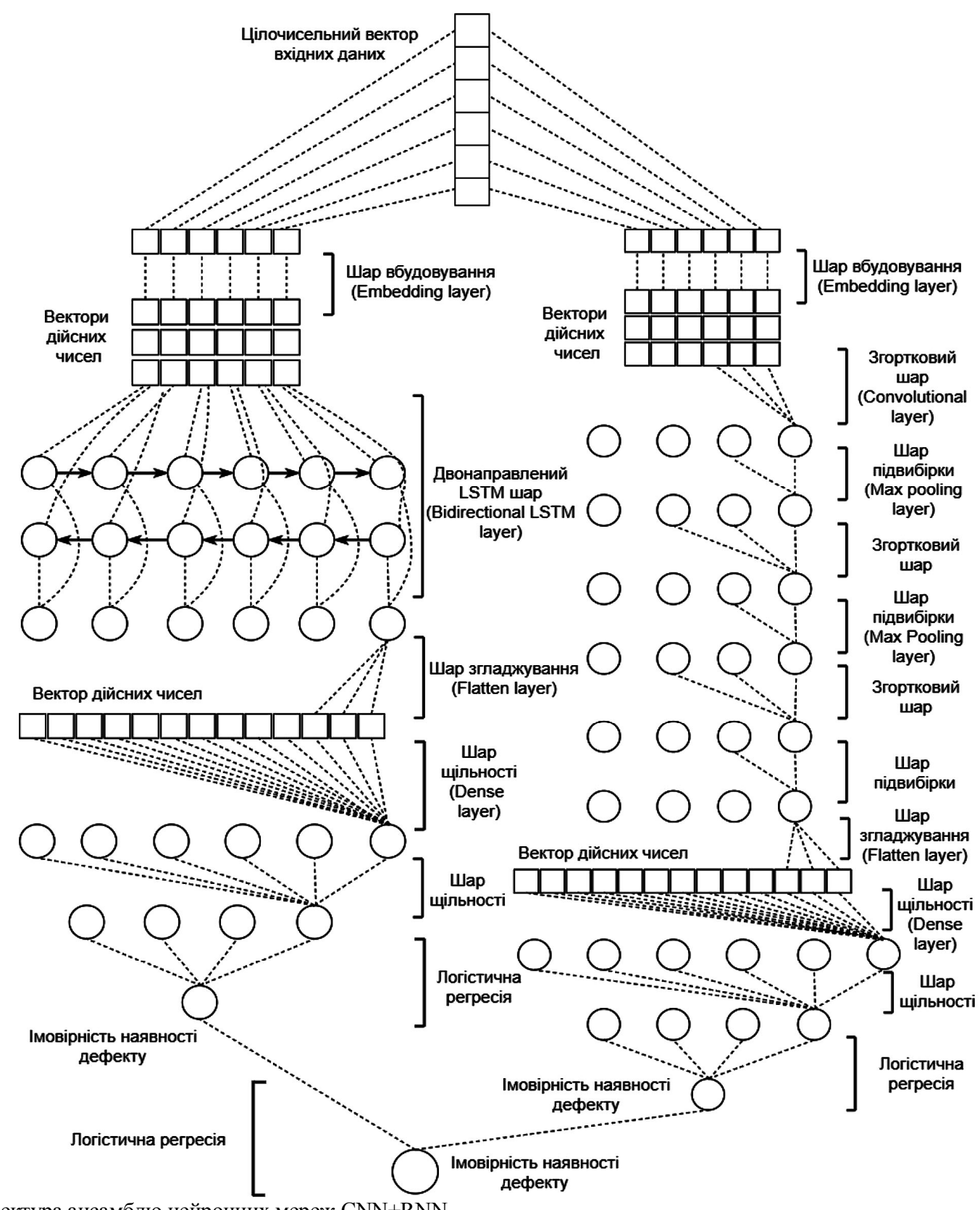

Рис. 3. Архітектура ансамблю нейронних мереж $\mathrm{CNN}+\mathrm{RNN}$ 
Під час навчання відбувається оптимізація коефіцієнтів моделі $\theta_{0} \ldots \theta_{n}$ у такий спосіб, щоб максимізувати правдоподібність події $P$.

Метрики оцінювання результатів. Результат кожного прогнозу наявності дефекту у фрагменті коду може належати до одного з чотирьох класів: ТР (True Positive), TN (Ture Negative), FP (False Positive), FN (False Negative). Ці класи ще називають матрицею спряженості результатів. На практиці застосовують спеціальні метрики, які базуються на зазначених класах $[5,10,3]$ :

- F-метрика - агрегований критерій, який гармонічно об'єднує дві інші базові метрики - точність та повноту:

$$
\begin{gathered}
\text { Tочність }=\frac{T P}{T P+F P}, \text { Повнота }=T N R=\frac{T P}{T P+F N}, \\
F=2 \times \frac{\text { Tочність } \times \text { Повнота }}{\text { Tочність }+ \text { Повнота }} .
\end{gathered}
$$

- G-метрика - агрегований критерій, який гармонічно об'єднує TPR і TNR та відображає поганий вплив хибних позитивних результатів на прогнозування:

$$
T N R=\frac{T N}{T N+F P}, G=\frac{2 \times T P R \times T N R}{T P R+T N R} .
$$

- MCC-коефіцієнт - описує цілу матрицю спряженості результатів єдиним значенням. Цей коефіцієнт коректніше описує точність моделі, якщо вхідні дані $є$ сильно незбалансовані, що відповідає нашому випадку:

$$
M C C=\frac{T P \times T N-F P \times F N}{\sqrt{(T P+F P) \times(T P+F N) \times(T N+F P) \times(T N+F N)}} .
$$

Значення метрик $\mathrm{F}$ та $\mathrm{G}$ перебувають в межах [0:1], а МСC коефіцієнта - в межах [-1;1]. Чим більше значення - тим краще.

Обговорення результатів дослідження. Реалізовано прототип програмного забезпечення для прогнозування дефектів у ПЗ алгоритмами глибинного навчання $\mathrm{CNN}, \mathrm{RNN}$ та їх об'єднанням CNN+RNN. Для реалізації прототипу було використано мову програмування Python. Побудову АСД-дерева виконано за допомогою Python бібліотеки javalang, а створення та навчання нейронних мереж - за допомогою бібліотеки Keras.

Задля збільшення розмірності датасету, файли з вихідним кодом розбивалися на класи. У такий спосіб було отримано 108 тис. класів, 3 яких 8 тис. містили дефекти. Для тренування нейронних мереж випадковим чином було обрано 80 \% класів, а решта були використані для проведення експериментів. На етапі збалансування тренувальних даних - дефектні класи дублювалися, допоки їх кількість не стала дорівнювати кількості недефектних класів. Натомість, дані для експериментів не збалансовувалися, щоб зберегти природу даних та достовірність результатів прогнозування.

Для аналізу точності запропонованої моделі, за результатами виконання експериментів обчислено значення F-метрики (рис. 4), G-метрики (рис. 5) та МCCкоефіцієнта (рис. 6) окремо для кожного проєкту з датасету [17].

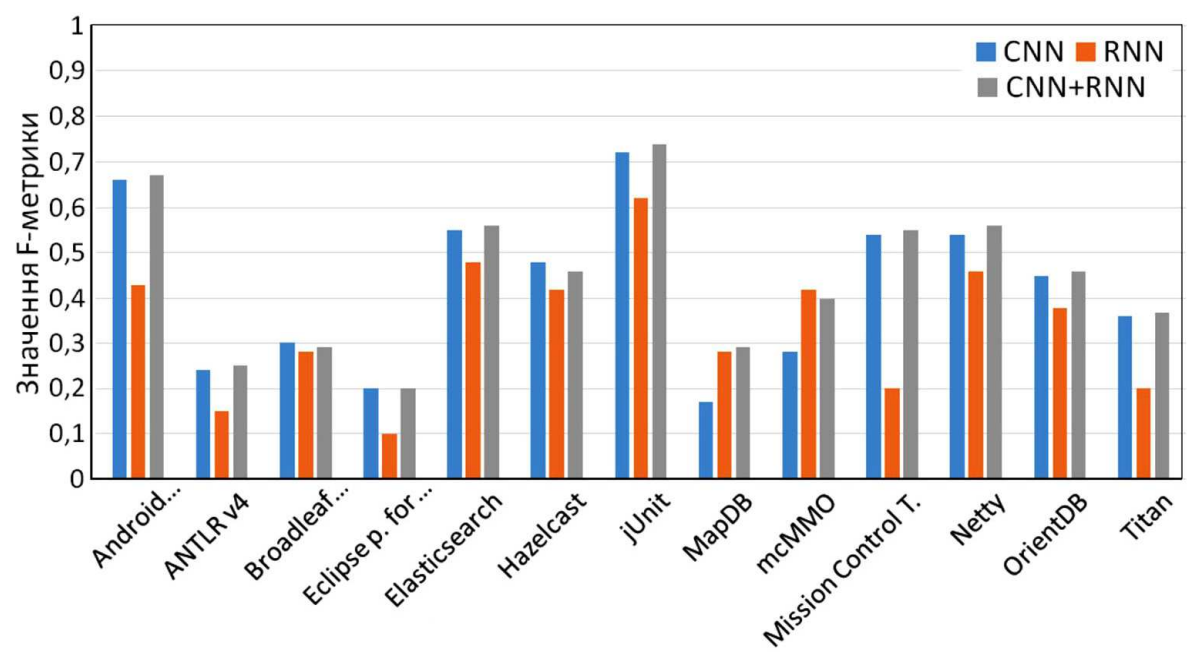

Pис. 4. Порівняння точності алгоритмів для кожного проєкту (F-метрика)

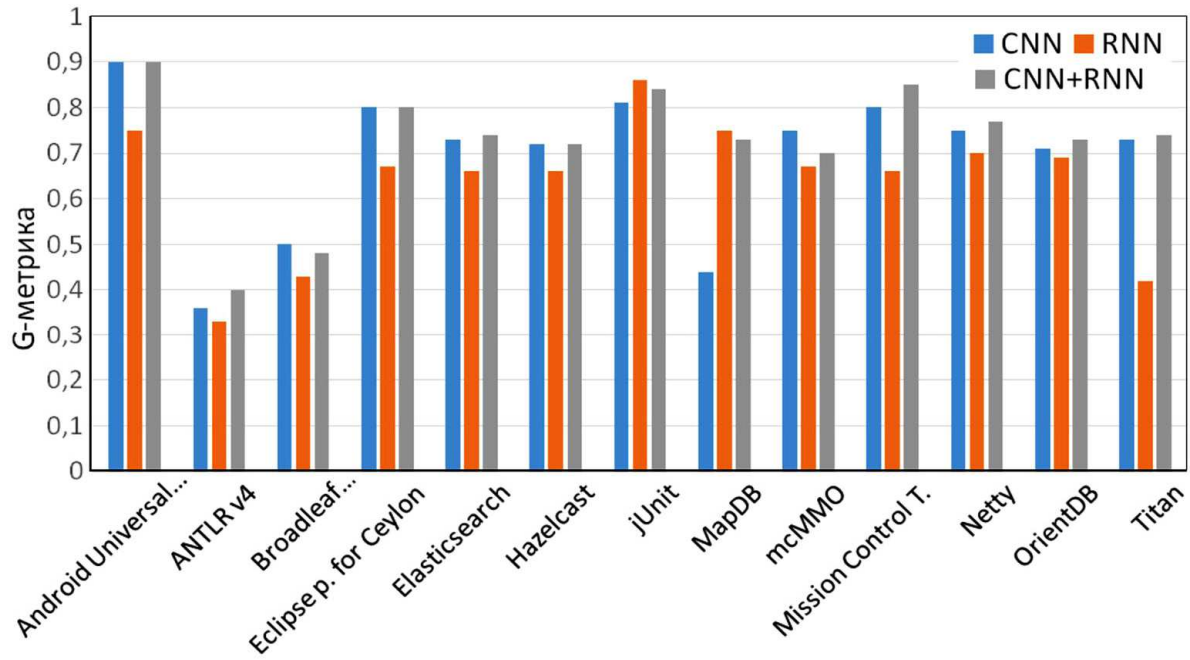

Pис. 5. Порівняння точності алгоритмів для кожного проєкту (G-метрика) 


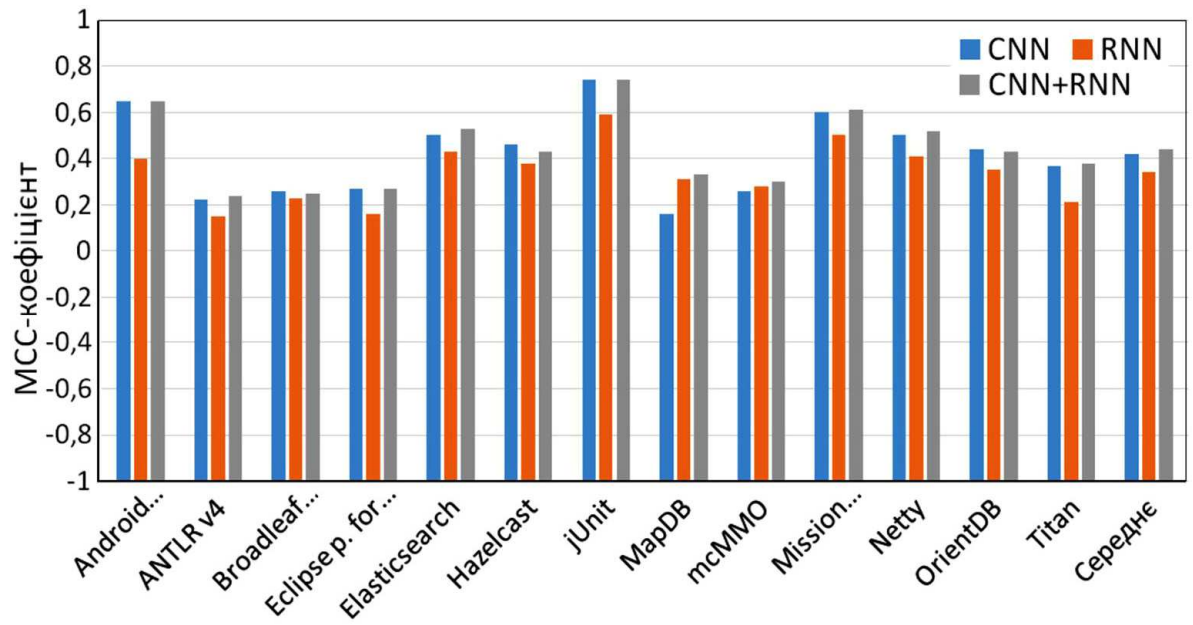

Рис. 6. Порівняння точності алгоритмів для кожного проєкту (МСС-коефіцієнт)

Виявлено, для 11-ти 3 13-ти проєктів (F-метрика) та 9-ти 3 11-ти проєктів (G-метрика та МСС-коефіцієнт) метод CNN+RNN показав кращі, або не гірші, результати, ніж інші алгоритми:

- F-метрика: точність $\mathrm{CNN}+\mathrm{RNN}$ на $10 \%$ вища, ніж у RNN та на $2 \%$, ніж у $\mathrm{CNN}$;

- G-метрика: точність CNN+RNN на $10 \%$ вища, ніж у RNN та на $2 \%$, ніж у CNN;

- MCC-коеф.: точність CNN+RNN на $9 \%$ вища, ніж у RNN та на $2 \%$, ніж у CNN.

За результатами аналізу обчислених метрик можна стверджувати, що покращення точності від поєднання $\mathrm{RNN}+\mathrm{CNN} \epsilon$ значнішим, ніж CNN чи RNN. Якщо порівнювати із $\mathrm{CNN}$ - то для більшості проєктів покращення було 1-10 \%. Порівняно із RNN досягнуто покращення 10-30\%.

Запропонований метод $\mathrm{CNN}+\mathrm{RNN}$ показав середню точність 72.3 \% (F-метрика). Водночас, попередні дослідження останньої модифікації $\mathrm{CNN}$ за F-метрикою продемонстрували точність $57 \%$ [10], а RNN - $72.8 \%$ [3]. Однак, задля усунення впливу природи вхідних даних (датасетів) та різниці у конфігурації нейронних мереж - коректно порівнювати точність методу $\mathrm{CNN}+\mathrm{RNN}$ тільки $з$ тими алгоритмами, які були реалізовані та перевірені в цьому дослідженні і в тих же умовах, що і було зроблено.

Перелік моментів, які можуть впливати на достовірність результатів:

- бібліотека javalang, яка використовувалася для аналізу вихідного коду, не підтримує деякі оператори мови Јava. Тому 3 датасету було видалено близько $6 \%$ файлів, які містять ці оператори;

- складно гарантувати аналогічні результати для різних датасетів чи проєктів, які були реалізовані використовуючи інший підхід чи мову програмування. Однак процес та моделі, представлені в даному дослідженні, є універсальними та можуть бути застосовані для будь-яких проєктів;

- як вже було зазначено, архітектура нейронних мереж CNN та RNN була частково запозичена із останніх подібних досліджень. Однак деякі із параметрів все ж підбиралися методом проб і помилок.

\section{Висновки}

З'ясовано, що для точного прогнозування дефектів у ПЗ доцільно використовувати алгоритми машинного навчання, а саме підвид цих алгоритмів - алгоритми глибинного навчання. Виявлено, що деякі модифікації алгоритмів глибинного навчання CNN та RNN дають найвищу на цей момент точність у прогнозуванні дефектів у ПЗ.

Досліджено увесь багатоетапний процес прогнозування дефектів у ПЗ, внаслідок чого виявлено, що метод побудови та навчання нейронної мережі може бути покращений завдяки поєднанню алгоритмів CNN та RNN, що дасть змогу знизити дисперсію та підвищити точність пошуку дефектів. Розвинуто метод прогнозування дефектів у ПЗ алгоритмами глибинного внаслідок поєднання двох алгоритмів CNN та RNN за допомогою бінарного класифікатора логістична регресія.

Реалізовано прототип програмної системи для прогнозування дефектів у П3 алгоритмами CNN+RNN та проведено навчання нейронних мереж на 108-ми тисячах фрагментах коду з 13-ти проєктів. Підтверджено, що представлений метод $\mathrm{CNN}+\mathrm{RNN}$ загалом дає на $2 \%$ точніші прогнози, ніж CNN, та на 8-10\% точніші, ніж RNN.

Надалі ця робота може розвиватися у напрямку дослідження точності запропонованого методу на інших наборах даних: реалізованих іншими мовами програмування $(\mathrm{C} / \mathrm{C}++/ \mathrm{C \#})$, або базованих на інших парадигмах програмування (процедурне програмування, функціональне програмування). Також перспективним $\epsilon$ дослідження поєднання більшої кількості алгоритмів машинного навчання. Це $є$ можливим, оскільки запропонований у цьому дослідженні підхід з використанням класифікатора логістична регресія дає змогу поєднувати довільну кількість різних за своєю природою алгоритмів. Тому задля подальшого підвищення точності можна додатково враховувати якісні метрики коду, або спробувати поєднати запропонований метод з іншим поширеним алгоритмом глибинного навчання - DBN.

\section{References}

1. Cai, Q., He, H., \& Man, H. (2014). Imbalanced evolving self-organizing learning. Neurocomputing, 133, 258-270. https://doi.org/10.1016/j.neucom.2013.11.010

2. Cramer, J. (2003). The Origins of Logistic Regression. SSRN Electronic Journal. https://doi.org/10.2139/ssm.360300

3. Fan, G., Diao, X., Yu, H., Yang, K., \& Chen, L. (2019). Software Defect Prediction via Attention-Based Recurrent Neural Network. Scientific Programming, 2019, 1-14. https://doi.org/10.1155/2019/6230953

4. Hassan, F., Fahiem, A., \& Tauseef, A. (2018). Review On Machine Learning Techniques For Software Defect Prediction. Technical Journal, 23(2), 63-71. 
5. Krizhevsky, A., Sutskever, I., \& Hinton, G. (2017). ImageNet classification with deep convolutional neural networks. Communications Of The ACM, 60(6), 84-90. https://doi.org/10.1145/3065386

6. Li, J., He, P., Zhu, J., \& Lyu, M. (2017). Software Defect Prediction via Convolutional Neural Network. 2017 IEEE International Conference On Software Quality, Reliability And Security (QRS). https://doi.org/10.1109/qrs.2017.42

7. Menzies, T., Milton, Z., Turhan, B., Cukic, B., Jiang, Y., \& Bener, A. (2010). Defect prediction from static code features: current results, limitations, new approaches. Automated Software Engineering, 17(4), 375-407. https://doi.org/10.1007/s10515-010-0069-5

8. Michael, B. (2019). Ensemble Methods. Machine Learning With Spark $^{\mathrm{TM}} \quad$ And Python ${ }^{\circledR}$, 221-263. https://doi.org/10.1002/9781119562023.ch6

9. Pak, C., Wang, T., \& Su, X. (2018). An Empirical Study on Software Defect Prediction Using Over-Sampling by SMOTE. International Journal Of Software Engineering And Knowledge Engineering, 28(06), 811-830. https://doi.org/10.1142/s0218194018500237

10. Pan, C., Lu, M., Xu, B., \& Gao, H. (2019). An Improved CNN Model for Within-Project Software Defect Prediction. Applied Sciences, 9(10), 2138 p. https://doi.org/10.3390/app9102138

11. Perreault, L., Berardinelli, S., Izurieta, C., \& Sheppard, J. (2017). Using Classifiers for Software Defect Detection. 26th International Conference on Software Engineering and Data Engineering, pp. 2-4.

12. Pushpavathi, T. P., Suma, V., \& Ramaswamy, V. (2014). Defect Prediction in Software Projects-Using Genetic Algorithm based Fuzzy C-Means Clustering and Random Forest Classifier. International Journal of Scientific \& Engineering Research, 5, 888-898.
13. Romi Satria, W. (2015). A Systematic Literature Review of Software Defect Prediction: Research Trends, Datasets, Methods and Frameworks. Journal of Software Engineering, 1(1), 1-16

14. Software Fail Watch. (2019). Tricentis. Retrieved from: https:/www.tricentis.com/wp-content/uploads/2019/01/SoftwareFails-Watch-5th-edition.pdf

15. Sonal, D., \& Kaur, G. (2013). Comparative Study of the Software Metrics for the complexity and Maintainability of Software Development. International Journal of Advanced Computer Science and Applications, 4(9), 161-164. https://doi.org/10.14569/IJACSA.2013.040925

16. Song, Q., Guo, Y., \& Shepperd, M. (2019). A Comprehensive Investigation of the Role of Imbalanced Learning for Software Defect Prediction. IEEE Transactions On Software Engineering, 45(12), 1253-1269. https://doi.org/10.1109/tse.2018.2836442

17. Tóth, Z., Gyimesi, P., \& Rudolf, R. (2016). Bug Database of GitHub Projects. Retrieved from: http://www.inf.u-szeged.hu/ ferenc/papers/GitHubBugDataSet/

18. Vu, N., Adel, H., Gupta, P., \& Schütze, H. (2016). Combining Recurrent and Convolutional Neural Networks for Relation Classification. Proceedings Of The 2016 Conference Of The North American Chapter Of The Association For Computational Linguistics: Human Language Technologies. https://doi.org/10.18653/v1/n16-1065

19. Wolpert, D. (1996). The Lack of A Priori Distinctions Between Learning Algorithms. Neural Computation, 8(7), 1341-1390. https://doi.org/10.1162/neco.1996.8.7.1341

20. Yamaguchi, F., Lottmann, M., \& Rieck, K. (2012). Generalized vulnerability extrapolation using abstract syntax trees. Proceedings Of The 28Th Annual Computer Security Applications Con$\begin{array}{llll}\text { ference } & \text { On } & - & \text { ACSAC }\end{array}$ https://doi.org/10.1145/2420950.2421003

T. P. Biletskyi, D. V. Fedasyuk

Lviv Polytechnic National University, Lviv, Ukraine

\section{SOFTWARE DEFECT PREDICTION VIA ENSEMBLE OF CONVOLUTIONAL NEURAL NETWORK AND RECURRENT NEURAL NETWORK}

The paper is devoted to the study of the software defect prediction process using deep learning algorithms. This process consists of several main steps: dataset search and preparation, parsing source code into abstract syntactic tree, tree traversal and tokens mapping, handling class imbalance, building and training neural networks. During the analysis of research papers we found that the application of the software defect prediction could facilitate the defects searching and prioritize testing efforts. However, machine learning algorithms, demonstrated in the recent studies, are not effective enough, showing an unstable accuracy ranging from $40 \%$ to $60 \%$. The study has discovered that the application of deep learning algorithms gives more accurate results than the other machine learning algorithms. In particular, the state-of-the-art versions of the CNN and RNN are on average $12-30 \%$ more accurate than traditional algorithms such as decision tree, logistic regression, naive Bayesian classifier, and random forest. However, the results still remain two variants for the various software projects. In order to reduce the variance and increase prediction accuracy, the study proposed improvements on the step of building and training neural networks. Namely, we proposed an improved model for software defect prediction based on the combination of state-of-the-art deep learning algorithms CNN and RNN together with binary classifier logistic regression. In order to correctly evaluate the accuracy of the proposed model, CNN and RNN based models were also built and trained. Training of each of the models was conducted on a dataset of 50,000 source code files obtained from 13 java projects. Experimental results showed that the CNN+RNN model gave on average 10-9\% higher accuracy than RNN and $2 \%$ higher accuracy than CNN. The accuracy results by each of the analysed software projects showed that in 11 out of 13 software projects the CNN + RNN model gives no less accuracy than CNN or RNN.

Keywords: software reliability; convolutional neural network; recurrent neural network; machine learning. 